\title{
Retraction Note: Controlling the properties of silver nanoparticles deposited on surfaces using supercritical carbon dioxide for surface-enhanced Raman spectroscopy
}

Michael J. Casciato • Galit Levitin •

Dennis W. Hess • Martha A. Grover

Published online: 7 August 2021

(C) Springer Nature B.V. 2021

Retraction Note to: J Nanopart Res (2012) 14:836

https://doi.org/10.1007/s11051-012-0836-2

The authors have retracted this article because the corresponding author, Michael J. Casciato, has voluntarily and without prompting informed the journal that figures and tables in this article were manipulated or falsified.

Michael J. Casciato has stated that he is solely responsible for these issues. All authors agree to this retraction.

Publisher's note Springer Nature remains neutral with regard to jurisdictional claims in published maps and institutional affiliations.

The original article can be found online at https://doi.org/ 10.1007/s11051-012-0836-2.

M. J. Casciato $(\bowtie) \cdot$ G. Levitin · D. W. Hess ·

M. A. Grover

School of Chemical \& Biomolecular Engineering, Georgia

Institute of Technology, Atlanta, GA 30332, USA

e-mail: michael.casciato@ chbe.gatech.edu 